\title{
KONVERGENSI STANDAR LAPORAN KEUANGAN KE STANDAR PELAPORAN KEUANGAN INTERNASIONAL, APA DAN BAGAIMANA
}

\author{
Heri Sukendar, W. \\ Jurusan Akuntansi, Fakultas Ekonomi dan Bisnis, Universitas Bina Nusantara, \\ Jln. K.H. Syahdan No. 9, Palmerah, Jakarta Barat 11480 \\ heris1024@yahoo.com
}

\begin{abstract}
This research aims to explain development of the convergence of financial accounting standards under IFRS outline being implemented in Indonesia. In the early part, background of the convergence from Indonesian GAAP to IFRS is discussed, both economically and politically to the latest developments in the convergence to IFRS at the present. Furthermore, it is also described the basic framework of the IFRS, which is the fundamental preparation of financial report under IFRS. At the end, this research will explain the impact of IFRS convergence on accounting and financial reporting systems, the impact of IFRS on business and the differences between IFRS and tax principles.
\end{abstract}

Keywords: IFRS convergence, G-20, basic principle, fair value, disclosure

\begin{abstract}
ABSTRAK
Penelitian ini bertujuan untuk menjelaskan perkembangan konvergensi standar akuntansi keuangan berdasarkan IFRS garis diimplementasikan di Indonesia. Pada bagian awal dibahas latar belakang yang mendorong konvergensi di Indonesia PSAK ke IFRS, baik secara ekonomi dan politik dengan perkembangan terbaru dalam konvergensi ke IFRS saat ini. Selain itu, juga dijelaskan kerangka dasar dari IFRS, yang merupakan dasar penyusunan laporan keuangan berdasarkan IFRS. Pada akhirnya, penelitian ini akan menjelaskan dampak konvergensi IFRS pada sistem pelaporan akuntansi dan keuangan, dampak IFRS pada bisnis dan perbedaan antara IFRS dan prinsip pajak.
\end{abstract}

Kata kunci: konvergensi IFRS, G-20, prinsip dasar, nilai wajar, pengungkapan 


\section{PENDAHULUAN}

Laporan keuangan merupakan bahasa yang digunakan oleh komunitas bisnis. Bahasa bisnis tersebut disusun berdasarkan standar akuntansi yang merupakan aturan-aturan pengukuran untuk laporan keuangan. Dalam perkembangannya, terdapat banyak dan berbedanya standar akuntansi yang berlaku sehingga menimbulkan masalah keterbandingan laporan keuangan. Kondisi ini tentu dapat dipahami karena dalam proses penyusunan standar akuntansi di suatu negara tidak terlepas dari pengaruh faktor-faktor lokal suatu negara (Wolk et al., 2001: 4) mengatakan "economic conditions have an impact upon both political factors and accounting theory". Hal ini yang menyebabkan standar dan praktik akuntansi di tiap-tiap negara terdapat perbedaan. Seiring dengan era globalisasi yang dimotori oleh perkembangan teknologi informasi dan komunikasi yang mengubah dunia internasional menjadi sebuah global village/ borderless, sejak saat inilah masalah perbedaan standar akuntansi mulai timbul.

Tidak dapat dipungkiri bahwa pengaruh Amerika Serikat dalam kancah internasional sangat kuat dalam hampir segala aspek kehidupan, acapkali kita sulit membedakan mana yang internasional dan mana yang Amerika. Faktanya, dalam dunia akuntansi saat ini standar akuntansi yang berlaku di Amerika Serikat yang disusun oleh Financial Accounting Standards Board (FASB) diikuti oleh beberapa negara, baik secara langsung maupun modifikasi. Sementara Internasional Accounting Standards (IASs), yang dikeluarkan oleh International Accounting Standards Committee (IASC), belum diikuti oleh semua negara, bahkan oleh negara-negara anggota yang tergabung dalam IASC tersebut.

Kasus kebangkrutan Enron pada tahun 2001, yang merupakan salah satu raksasa energi Amerika Serikat dan kasus kebangkrutan Lehman Brothers pada tahun 2008, yang merupakan salah satu raksasa bank investasi Amerika Serikat, mempunyai dampak yang merugikan investor global dan perekonomian di seluruh dunia. Fakta menunjukkan bahwa salah satu penyebab kebangkrutan tersebut adalah masalah akuntansi yang disalahgunakan dan standar akuntansi yang kurang baik. Standar akuntansi yang kurang baik dan berbeda-beda mengakibatkan informasi keuangan yang disajikan dalam laporan keuangan tidak dapat dibandingkan, tidak relevan, tidak transparan bagi semua stakeholder. Kebutuhan akan likuiditas pasar uang dan modal di hampir semua negara dalam mensejahterakan rakyatnya menuntun mereka kepada kesatuan standar tunggal pelaporan akuntansi berkualitas tinggi dan kerangka akuntansi berbasiskan prinsip, yang meliputi penilaian profesional yang kuat dengan disclosures yang jelas dan transparan mengenai substansi ekonomi transaksi, penjelasan hingga mencapai kesimpulan tertentu, dan akuntansi terkait transaksi tersebut. Dengan demikian, pengguna laporan keuangan dapat dengan mudah membandingkan informasi keuangan entitas antarnegara di berbagai belahan dunia. Kesemuanya itu telah disepakati dalam International Accounting Standards, yang lebih dikenal sebagai International Financial Reporting Standards (IFRS) yang diyakini memberikan manfaat sebagai berikut (1) Memudahkan pemahaman atas laporan keuangan dengan penggunaan Standar Akuntansi Keuangan yang dikenal secara internasional (enhance comparability), (2) Meningkatkan arus investasi global melalui transparansi, (3) Menurunkan biaya modal dengan membuka peluang fund raising melalui pasar modal secara global, dan (4) Menciptakan efisiensi penyusunan laporan keuangan.

Salah satu keputusan penting dalam pertemuan pemimpin negara-negara G-20 yang digelar di Pittsburgh tanggal 24-25 September 2009, di mana Indonesia adalah salah satu anggota G-20 adalah butir ke 14 Deklarasi Pittsbugh, yang menyatakan bahwa para pemimpin negara-negara G-20 sepakat untuk menggandakan upaya agar konvergensi standar akuntansi global yang berkualitas tinggi secara internasional dapat diselesaikan pada Juni 2011. Penelitian ini bertujuan untuk membahas kesiapan Indonesia menyelesaikan hasil keputusan tersebut, apakah konvergensi standar laporan keuangan ke standar pelaporan keuangan internasional akan berdampak terhadap sistem akuntansi dan pelaporan, 
bisnis serta perpajakan di Indonesia, di balik kebanggaan pengakuan kekuatan Indonesia sebagai satusatunya anggota G-20 dari Asia Tenggara.

Konvergensi dapat diartikan sebagai suatu keadaan menuju satu titik pertemuan atau memusat. Konvergensi standar akuntansi pada dasarnya adalah penyamaan bahasa bisnis. Setiap negara memiliki lembaga pengatur standar pelaporan keuangan. Indonesia memiliki Ikatan Akuntan Indonesia (IAI) yang mengeluarkan Pernyataan Standar Akuntansi Keuangan (PSAK) sebagai satu-satunya standar yang diterima sebagai "bahasa bisnis" perusahaan-perusahaan di Indonesia. Amerika Serikat memiliki Generally Accepted Accounting Principles (GAAP) yang dirilis oleh Financial Accounting Standard Board (FASB). Uni Eropa memiliki International Accounting Standard (IAS) yang dikeluarkan oleh International Accounting Standard Board (IASB) dan seterusnya. Setiap negara menggunakan standar pelaporan yang sangat mungkin divergen antara satu dengan yang lain. Tidak ada jaminan bahwa laporan-laporan keuangan yang disajikan di antara negara-negara yang berbeda tersebut dapat dibaca dengan bahasa yang sama. Perbedaan standar ini pada ujungnya juga akan menghambat para pelaku bisnis internasional dalam mengambil keputusan bisnisnya.

Sejauh ini yang leading menjadi standar acuan adalah International Financial Reporting Standards (IFRS) yang dikeluarkan oleh International Accounting Standard Board (IASB). IASB adalah badan pengatur standar dari International Accounting Standards Committee Foundation, sebuah lembaga independen nirlaba internasional yang bergerak di bidang pelaporan keuangan yang berkedudukan di Inggris. Saat ini, lebih dari 100 negara telah diwajibkan atau membolehkan penerapan IFRS dan diperkirakan akan semakin banyak negara di dunia menggunakan IFRS. Bahkan 10 negara yang pasar modalnya sudah mendunia telah melakukan konvergensi ke IFRS, yaitu, Jepang, Inggris, Perancis, Kanada, Jerman, Hongkong, Spanyol, Switzerland, Australia, termasuk Amerika Serikat sudah menyatakan akan melakukan konvergensi ke IFRS. Untuk Indonesia, sejak revisi PSAK tahun 1994, IAI telah memutuskan untuk melakukan harmonisasi standar PSAK kepada IFRS. Selanjutnya, harmonisasi tersebut diubah menjadi adopsi yang ditujukan dalam bentuk konvergensi. Sebagai langkah awal, Dewan Standar Akuntansi Keuangan Ikatan Akuntan Indonesia (DASK-IAI) akan mengkonvergensikan PSAK secara penuh dengan IFRS melalui 3 tahapan, yaitu tahap adopsi, persiapan akhir, dan implementasi. Tahap adopsi dilakukan pada periode 2008-2011, meliputi aktivitas adopsi seluruh PSAK ke IFRS, persiapan infrastruktur, dan evaluasi terhadap PSAK yang berlaku. Dengan demikian, konvergensi PSAK diharapkan dapat meningkatkan kualitas standar akuntansi keuangan dan mengurangi biaya penyusunan, meningkatkan kredibilitas dan kegunaan laporan keuangan melalui peningkatan kualitas dan daya banding serta menyelaraskan dengan pengaturan yang berlaku secara internasional.

Tentu saja bukan pekerjaan mudah untuk merujuk 62 standar yang dimiliki PSAK dengan 37 standar yang dimiliki IFRS. Saat ini masih terdapat perbedaan yang cukup besar antara PSAK dan IFRS, bahkan terdapat 20 standar PSAK atau 32\% yang tidak dapat diperbandingkan. Jika dibandingkan dengan IFRS, masih terdapat perbedaan yang cukup signifikan meliputi financial instrument, investment property, business combination, property, plan and equipment, intangible assets, service concession agreement, presentation of fiinancial statement, leases, insurance contract, accounting for banking yang akan dihapus, exploration and evaluation of mineral assets, agriculture, dan accounting for reporting currencies serta perbedaan-perbedaan utama lainnya.

Sasaran konvergensi yang telah dicanangkan IAI pada tahun 2012 adalah merevisi PSAK agar secara material sesuai dengan IFRS versi 1 Januari 2009, yang berlaku efektif tahun 2011/2012. Untuk itu, 29 Standar Akuntansi Keuangan (SAK) masuk dalam program konvergensi IFRS yang dicanangkan DSAK-IAI tahun 2009 dan 2010. Banyaknya standar yang harus dilaksanakan dalam program konvergensi ini menjadi tantangan yang cukup berat bagi DSAK-IAI periode 2009-2012. Skema menuju konvergensi penuh dengan IFRS pada tahun 2012 dapat dijabarkan sebagai berikut (1) Pada akhir 2010, diharapkan seluruh IFRS sudah diadopsi dalam PSAK, (2) Tahun 2011 merupakan tahun penyiapan seluruh struktur pendukung untuk implementasi PSAK yang sudah mengadopsi 
seluruh IFRS, dan (3) Tahun 2012 merupakan tahun implementasi, di mana PSAK yang berbasis IFRS wajib diterapkan oleh perusahaan-perusahan yang memiliki akuntabilitas public.

Revisi tahun 2007 yang merupakan bagian dari rencana jangka panjang IAI menghasilkan revisi 5 PSAK, yang merupakan revisi yang ditujukan untuk konvergensi PSAK dan IFRS serta reformat beberapa PSAK lain dan penerbitan PSAK yang baru. PSAK yang direvisi dan ditujukan dalam rangka tujuan konvergensi PSAK terhadap IFRS adalah PSAK 13 tentang properti investasi, PSAK 16 tentang aset tetap, PSAK 30 tentang sewa, PSAK 50 tentang instrumen keuangan seperti penyajian dan pengungkapan, dan PSAK 55 tentang instrumen keuangan seperti pengakuan dan pengukuran. PSAK revisi tahun 2007 ini dikumpulkan dalam buku yang disebut dengan Standar Akuntansi Keuangan per 1 September 2007 dan mulai berlaku sejak tanggal 1 Januari 2008. Adapun posisi IFRS/IAS yang sudah diadopsi hingga saat ini dan sudah diadopsi pada tahun 2009 dan 2010 adalah seperti yang tercantum dalam Tabel 1 sampai 3.

Tabel 1 IFRS/IAS yang Telah Diadopsi

ke Dalam PSAK hingga 31 Desember 2008

\begin{tabular}{ccl}
\hline No. Urut & No. IAS/IFRS & \multicolumn{1}{c}{ Tentang } \\
\hline 1 & IAS 2 & Inventories \\
2 & IAS 10 & Events after balance sheet date \\
3 & IAS 11 & Construction contracts \\
4 & IAS 16 & Property, plant and equipment \\
5 & IAS 17 & Leases \\
6 & IAS 18 & Revenues \\
7 & IAS 19 & Employee benefits \\
8 & IAS 23 & Borrowing costs \\
9 & IAS 32 & Financial instruments: presentation \\
10 & IAS 39 & Financial instruments: recognition and \\
11 & .IAS 40 & measurement Investment property \\
\hline
\end{tabular}

Tabel 2 IFRS/IAS yang Telah Diadopsi

ke Dalam PSAK per 23 Desember Tahun 2009

\begin{tabular}{ccl}
\hline No. Urut & No. IAS/IFRS & \\
\hline 1 & IFRS 2 & Share-based payment \\
2 & IFRS 4 & Insurance contracts \\
3 & IFRS 5 & Non-current assets held for sale and discontinued operations \\
4 & IFRS 6 & Exploration for and evaluation of mineral resources \\
5 & IFRS 7 & Financial instruments: disclosures \\
6 & IAS 1 & Presentation of financial statements \\
7 & IAS 27 & Consolidated and separate financial statements \\
8 & IAS 28 & Investments in associates \\
9 & IFRS 3 & Business combination \\
10 & IFRS 8 & Segment reporting \\
11 & IAS 8 & Accounting policies, changes in accounting estimates and \\
12 & IAS 12 & errors \\
13 & IAS 21 & Income taxes \\
14 & IAS 26 & The effects of changes in foreign exchange rates \\
15 & IAS 31 & Accounting and reporting by retirement benefit plans \\
16 & IAS 36 & Interests in joint ventures \\
17 & IAS 37 & Impairment of assets \\
18 & IAS 38 & Provisions, contingent liabilities and contingent assets \\
& & Intangible assets \\
\hline
\end{tabular}


Tabel 3 IFRS/IAS yang Akan Diadopsi

ke Falam PSAK pada Tahun 2010

\begin{tabular}{|c|c|c|}
\hline No. Urut & No. IAS/IFRS & Tentang \\
\hline 1 & IAS 7 & Cash flow statements \\
\hline 2 & IAS 20 & $\begin{array}{l}\text { Accounting for government grants and disclosure of } \\
\text { government assistance }\end{array}$ \\
\hline 3 & IAS 24 & Related party disclosures \\
\hline 4 & IAS 29 & Financial reporting in hyperinflationary economies \\
\hline 5 & IAS 33 & Earning per share \\
\hline 6 & IAS 34 & Interim financial reporting \\
\hline 7 & IAS 41 & Agriculture \\
\hline
\end{tabular}

Dalam penyusunan dan penyajian laporan keuangan, kerangka kerja (framework) merupakan prinsip dasar dari IFRS. Kerangka dasar IFRS dimulai dengan asumsi dasar penyusunan dan penyajian laporan keuangan. Ada 2 asumsi dasar yang digunakan dalam IFRS, yaitu (1) Accrual basis adalah asumsi bahwa efek dari semua transaksi dan kejadian diakui apabila sudah terjadi/direalisasikan, bukan pada saat kas diperoleh atau dibayarkan; (2) Going concern adalah asumsi bahwa suatu usaha dijalankan untuk periode jangka panjang. Setelah asumsi dasar selanjutnya adalah karakteristik kualitatif dari suatu laporan keuangan yang meliputi understandability, reliability, comparability, relevance, constraints on relevant and reliable information, dan true and fair view/fair presentation.

Karakteristik IFRS tersebut dapat diuraikan dalam 5 pendekatan dasar sebagai berikut. Pertama, pendekatan basis prinsip (principle-based approach) adalah pendekatan yang menempatkan penekanan lebih besar pada penafsiran dan penerapan prinsip-prinsip, dengan fokus khusus pada semangat prinsip yang diterapkan. Pendekatan ini menetapkan/mengatur IFRS hanya pada prinsipprinsip utamanya sehingga tidak memiliki standar-standar yang spesifik untuk industri. Kalaupun terdapat standar mengenai kontrak asuransi (IFRS 4 Insurance contract), standar tersebut tidak mengatur entitas asuransi, tapi entitas apapun yang memiliki kontrak asuransi. US-GAAP dan SAK kita sebelumnya yang berbasis pengaturan (rule based) lebih detail dan kompleks juga memiliki standar-standar berbasis industry, misalnya adalah standar mengenai pengakuan pendapatan. Di IFRS, pengakuan pendapatan hanya diatur pada 2 standar, yaitu IAS 18 Revenue dan IAS 11 Construction Contracts. Sementara itu, standar akuntansi di US, misalnya memiliki sekitar 100 standar yang di dalamnya berisi pengakuan pendapatan yang berbeda-beda pada tiap industri. Jadi, dimungkinkan hasil yang berbeda untuk substansi ekonomi yang sama dalam industri yang berbeda (IASB, 2009).

Kedua, pendekatan standar yang memerlukan penilaian substansi transaksi dan evaluasi, apakah presentasi akuntansi mencerminkan realitas ekonomi. Karakteristik ini menekankan substansi dari transaksi dan evaluasi yang mencerminkan realitas ekonomi, contohnya di dalam IAS 38, juga PSAK 19 (revisi 2010) disebutkan bahwa aset tidak berwujud tidak lagi memiliki maksimum umur manfaat. Perusahaan harus menilai berapa umur eknomis aset tidak berwujud. Bahkan, apabila perusahaan tidak bisa melihat batas akhir kapan manfaat ekonomis aset tidak berwujud tersebut berakhir, perusahaan dapat membuatnya menjadi aset tidak berwujud dengan umur manfaat tak terbatas. Aset tidak berwujud dengan umur manfaat tidak terbatas diperlakukan sama seperti goodwill, yakni dikenai uji penurunan nilai setiap tahun dan tidak diamortisasi. Ketiga, pendekatan yang berfokus pada kebutuhan untuk penilaian profesional dalam hal penyelesaian berwujud dengan umur manfaat tidak terbatas diperlakukan sama seperti goodwill, yakni dikenai uji penurunan nilai setiap tahun dan tidak diamortisasi. Karakteristik ini menunjukkan bahwa penilaian profesional merupakan hal yang terpenting dalam penyelesaian masalah akuntansi. Hal ini dikaitkan dengan penentuan umur ekonomis suatu aset tidak berwujud, yang berdasarkan kriteria dan faktor yang diterima secara umum. 
Keempat, pendekatan pada penggunan yang lebih besar nilai wajar (fair value) sebagai dasar pengukuran penekanan 2 arah untuk memperoleh pengukuran yang dapat diandalkan. Kriteria ini berlawanan dengan PSAK yang dianut sebelumnya, di mana penilaian aset haruslah berdasarkan harga perolehan (historical cost). Kelima, pendekatan persyaratan pengungkapan yang lebih ektensif. Karakteristik ini menuntut pengungkapan yang lebih ekstensif dibandingkan dengan PSAK terdahulu. Fokus kepada penyiapan laporan keuangan tidak lagi cukup, dalam era IFRS di samping laporan keuangan, pengungkapan atas hal-hal yang mendasari perlu disampaikan dalam catatan atas laporan keuangan (CALK).

\section{Unsur-unsur dari Laporan Keuangan}

Posisi keuangan suatu perusahaan pada dasarnya disajikan di dalam Laporan Posisi Keuangan (Statement of Financial Position). Elemen-elemennya meliputi (1) Aset adalah sumber yang dikuasai oleh perusahaan sebagai akibat dari peristiwa masa lalu dan dari mana manfaat ekonomi di masa depan diharapkan akan diperoleh perusahaan; (2) Liabilitas merupakan hutang perusahaan masa kini yang timbul dari peristiwa masa lalu, penyelesaiannya diharapkan mengakibatkan arus keluar dari sumber daya perusahaan yang mengandung manfaat ekonomi; (3) Ekuitas adalah hak residual atas aset perusahaan setelah dikurangi semua kewajiban. Kinerja keuangan suatu perusahaan umumnya disajikan dalam sebuah laporan penghasilan bersih (income statement) atau laporan laba rugi (profit and loss account). Unsur dari income statement atau unsur-unsur yang mengukur kinerja keuangan adalah sebagai berikut; (4) Penghasilan (revenues) adalah peningkatan dalam manfaat ekonomi dalam suatu periode akuntansi dalam bentuk pemasukan atau kenaikan aset, atau penurunan kewajiban yang mengakibatkan kenaikan ekuitas. Namun, tidak termasuk kontribusi yang dilakukan oleh peserta ekuitas, misalnya modal perseorangan, persekutuan, dan pemegang saham; (5) Beban (expenses) adalah penurunan dalam manfaat ekonomi dalam periode akuntansi dalam bentuk pengeluaran, atau deplesi aset atau timbulnya liabilitas sebagai akibat penurunan ekuitas. Suatu pos diakui dalam laporan keuangan apabila ada kemungkinan bahwa manfaat ekonomi yang berkaitan dengan pos tersebut akan mengalir dari atau ke dalam perusahaan, pos tersebut mempunyai nilai atau biaya yang dapat diukur dengan andal, dan stabilitas.

Paragraf 99, pengukuran adalah proses penetapan jumlah uang untuk mengakui dan memasukkan setiap unsur laporan keuangan dalam neraca dan laporan laba rugi. Proses ini menyangkut pemilihan dasar pengukuran tertentu. Paragraf 100, sejumlah dasar pengukuran yang berbeda digunakan dalam derajat dan kombinasi yang berbeda dalam laporan keuangan. Berbagai dasar pengukuran tersebut adalah sebagai berikut (1) Biaya historis. Aset dicatat sebesar pengeluaran kas (atau setara kas) yang dibayar atau sebesar nilai wajar dari imbalan (consideration) yang diberikan untuk memperoleh aset tersebut pada saat perolehan. Kewajiban dicatat sebesar jumlah yang diterima sebagai penukar dari kewajiban (obligation), atau dalam keadaan tertentu (misalnya pajak penghasilan), dalam jumlah kas (atau setara kas) yang diharapkan akan dibayarkan untuk memenuhi kewajiban dalam pelaksanaan usaha normal; (2) Biaya kini (current cost). Aset dinilai dalam jumlah kas (atau setara kas) yang seharusnya dibayar bila aset yang sama atau setara aset diperoleh sekarang. Kewajiban dinyatakan dalam jumlah kas (atau setara kas) yang tidak didiskontokan (undiscounted) yang mungkin akan diperlukan untuk menyelesaikan kewajiban (obligation) sekarang; (3) Nilai realisasi/penyelesaian (realisable/settlement value). Aset dinyatakan dalam jumlah kas (atau setara kas) yang dapat diperoleh sekarang dengan menjual aset dalam pelepasan normal (orderly disposal). Kewajiban dinyatakan sebesar nilai penyelesaian, yaitu jumlah kas (atau setara kas) yang tidak didiskontokan yang diharapkan akan dibayarkan untuk memenuhi kewajiban dalam pelaksanaan usaha normal; (4) Nilai sekarang (present value). Aset dinyatakan sebesar arus kas masuk bersih di masa depan yang didiskontokan ke nilai sekarang dari pos, yang diharapkan dapat memberikan hasil dalam pelaksanaan usaha normal. Kewajiban dinyatakan sebesar arus kas keluar bersih di masa depan yang didiskontokan ke nilai sekarang, yang diharapkan akan diperlukan untuk menyelesaikan kewajiban dalam pelaksanaan usaha normal. 
Paragraf 101, dasar pengukuran yang lazimnya digunakan perusahaan dalam penyusunan laporan keuangan adalah biaya historis. Ini biasanya digabungkan dengan dasar pengukuran yang lain, misalnya persediaan biasanya dinyatakan sebesar nilai terendah dari biaya historis atau nilai realisasi bersih (lower of cost or net realizable value), akuntansi dana pensiun menilai aset tertentu berdasarkan nilai wajar (fair value). Paragraf 102, konsep modal keuangan dianut oleh sebagian besar perusahaan dalam penyusunan laporan keuangan. Menurut konsep modal keuangan seperti uang atau daya beli yang diinvestasikan, modal adalah sinonim dengan aset bersih atau ekuitas perusahaan. Menurut konsep modal fisik seperti kemampuan usaha, modal dipandang sebagai kapasitas produktif perusahaan, yang didasarkan pada, misalnya unit output per hari.

Paragraf 103, pemilihan konsep modal yang sesuai bagi perusahaan harus didasarkan pada kebutuhan pengguna laporan keuangan. Jadi, konsep modal keuangan seharusnya dianut kalau pengguna laporan keuangan terutama berkepentingan dengan pemeliharaan modal nominal atau daya beli dari modal yang diinvestasikan. Namun demikian, kalau pengguna berkepentingan dengan kemampuan usaha perusahaan, seharusnya digunakan konsep modal fisik. Konsep yang dipilih menunjukkan sasaran yang akan dicapai dalam penetapan laba, bahkan meskipun operasionalisasi konsep tersebut tidak terlepas dari kesulitan pengukurannya.

Paragraf 104, konsep modal dalam paragraf 102 menciptakan 2 konsep pemeliharaan modal, yaitu (1) Pemeliharaan modal keuangan (financial capital maintenance). Menurut konsep ini, laba hanya diperoleh kalau jumlah finansial (atas uang) dari aset bersih pada akhir periode melebihi jumlah finansial (atas uang) dari aset bersih pada awal periode, setelah memasukkan kembali setiap distribusi kepada, dan mengeluarkan setiap kontribusi dari para pemilik selama periode. Pemeliharaan modal keuangan dapat diukur, baik dalam satuan moneter nominal (nominal monetary units) atau dalam satuan daya beli yang konstan (units of constant purchasing power); dan (2) Pemeliharaan modal fisik (Physical capital maintenance). Menurut konsep ini, laba hanya diperoleh kalau kapasitas produkstif fisik (atau kemampuan usaha) pada akhir periode melebihi kapasitas produktif fisik pada awal periode setelah memasukkan kembali setiap distribusi kepada, dan mengeluarkan setiap kontribusi dari, para pemilik selama suatu periode.

Tiga konsep modal yang didefinisIkan dalam IFRS selama inflasi dan deflasi rendah, yaitu (1) Modal fisik (physical capital). Lihat paragraf 102, (2) Modal nominal keuangan (nominal financial capital). Lihat paragraf 104, dan (3) Modal daya beli keuangan konstan (constant purchasing power financial capital). Lihat paragraf 104. Sedangkan 3 konsep pemeliharaan modal (capital maintenance) yang diotorisasi oleh IFRS dalam periode inflasi dan deflasi yang rendah, yaitu (1) Pemeliharaan modal fisik (physical capital maintenance) adalah pilihan dalam periode inflasi dan deflasi yang rendah. Model akuntansi biaya kini yang dijelaskan oleh IFRS. Lihat paragraf 106, (2) Pemeliharaan modal keuangan (financial capital maintenance) dalam satuan moneter nominal (nominal monetary units) / historical cost accounting adalah diotorisasikan oleh IFRS, namun tidak diharuskan - sebagai opsi selama periode inflasi dan deflasi yang rendah. Lihat paragraf 104(a). Pemeliharaan modal keuangan (financial capital maintenance) dalam satuan moneter nominal (nominal monetary units) sendiri dalam periode inflasi dan deflasi adalah suatu kekeliruan, suatu hal yang mustahil untuk mempertahankan nilai wajar dari modal keuangan secara konstan dengan pengukuran dalam unit moneter nominal sendiri selama inflasi dan deflasi, (3) Pemeliharaan modal keuangan (financial capital maintenance) dalam satuan daya beli konstan (units of constant purchasing power) adalah diotorisasikan oleh IFRS, namun tidak diharuskan - opsi dalam periode inflasi dan deflasi yang rendah. Lihat paragraf 104(a). Diharuskan dalam IAS 29 selama periode hiper-inflasi. Hanya pemeliharaan modal dalam satuan daya beli konstan yang dapat memelihara nilai wajar dari modal keuangan konstan selama inflasi dan deflasi di semua perusahaan yang paling tidak impas - ceteris paribus. 
Paragraf 105, konsep pemeliharaan modal berkepentingan dengan bagaimana perusahaan mendefinisikan modal yang ingin dipelihara (dipertahankan). Konsep ini mengaitkan konsep modal dengan konsep laba karena memberikan dasar rujukan untuk mengukur laba. Konsep ini juga merupakan prasyarat untuk membedakan antara imbal hasil atas modal perusahaan (return on capital) dan pengembalian modal (return on capital); hanya arus masuk aset yang melebihi jumlah yang dibutuhkan untuk memelihara modal dapat dianggap laba dan karenanya merupakan imbalan modal. Oleh karena itu, laba merupakan jumlah residual yang tertinggal setelah semua beban (termasuk penyesuaian pemeliharaan modal, kalau ada) dikurangkan pada penghasilan. Kalau beban melebihi penghasilan, maka jumlah residualnya merupakan kerugian bersih.

Paragraf 106, konsep pemeliharaan modal fisik memerlukan penggunaan dasar pengukuran biaya kini (current cost). Namun demikian, konsep pemeliharaan modal keuangan tidak memerlukan penggunaan dasar pengukuran tertentu. Pemilihan dasar dalam konsep ini bergantung pada jenis modal keuangan yang ingin dipelihara perusahaan. Paragraf 107, perbedaan pokok antara 2 konsep pemeliharaan modal ini adalah perlakuan terhadap pengaruh perubahan harga aset dan kewajiban perusahaan. Dalam pengertian umum, perusahaan telah memelihara modalnya kalau modal yang dimiliki pada akhir periode sama dengan pada awal periode. Setiap jumlah di atas atau yang melebihi yang diperlukan untuk memelihara modal pada awal tahun merupakan laba.

Paragraf 108, menurut konsep pemeliharaan modal keuangan yang mendefinisikan modal dalam satuan moneter nominal, laba merupakan kenaikan dalam modal uang nominal selama suatu periode. Jadi, kenaikan harga aset yang dimiliki selama satu periode, yang secara konvensional disebut keuntungan akibat kepemilikan (holding gains), secara konseptual disebut laba. Namun demikian, jumlahnya tidak diakui sampai aset tersebut dilepaskan dalam transaksi pertukaran. Jika konsep pemeliharaan modal keuangan didefinisikan dalam satuan daya beli konstan, maka laba merupakan kenaikan daya beli yang diinvestasikan selama suatu periode. Jadi, hanya bagian dari kenaikan harga aset yang melebihi kenaikan tingkat harga umum disebut laba. Sisa kenaikan yang lain diperlakukan sebagai penyesuaian pemeliharaan modal dan karenanya merupakan bagian dari ekuitas. Paragraf 109, menurut konsep pemeliharaan modal fisik yang mendefinisikan modal dalam kapasitas produktif fisik, laba merupakan kenaikan modal tersebut selama suatu periode. Semua perubahan harga yang mempengaruhi aset dan kewajiban perusahaan dipandang sebagai perubahan dalam pengukuran kapasitas produktif fisik perusahaan. Oleh karena itu, jumlahnya diperlakukan sebagai penyesuaian pemeliharaan modal yang merupakan bagian ekuitas dan bukan merupakan laba.

Paragraf 110, pemilihan dasar pengukuran dan konsep pemeliharaan modal akan menentukan model akuntansi yang digunakan dalam penyusunan laporan keuangan. Model akuntansi yang berbeda menunjukkan derajat relevansi dan keandalan yang berbeda dan seperti halnya dalam bidang lain, manajemen harus mencari keseimbangan antara relevansi dan keandalan. Kerangka dasar ini berlaku untuk serangkaian model akuntansi dan memberikan bimbingan dalam penyusunan dan penyajian laporan keuangan, yang dibentuk menurut model yang dipilih. Saat ini IASB tidak bermaksud merumuskan suatu model tertentu, kecuali dalam keadaan luar biasa seperti perusahaan yang melaporkan dalam mata uang di suatu perekonomian yang dilanda hiper-inflasi. Namun demikian, hal ini akan ditinjau kembali dengan memperhatikan perkembangan di masa depan.

\section{Persyaratan IFRS}

Laporan keuangan menurut IFRS terdiri dari (IAS1.8) hal-hal sebagai berikut (1) Laporan posisi keuangan (a statement of financial position), (2) Laporan pendapatan komprehensif ( $a$ comprehensive income statement), (3) Laporan perubahan ekuitas atau laporan pengakuan pendapatan atau beban (either a statement of changes in equity (SOCE) or a statement of recognised income or expense ("SORIE")), (4) Laporan arus kas (a cash flow statement or statement of cash flows), dan (5) Catatan, termasuk ringkasan kebijakan akuntansi yang penting (notes, including a summary of the significant accounting policies). 
Informasi komparatif disajikan untuk periode pelaporan sebelumnya (IAS 1.36). Suatu perusahan yang menyiapkan akun-akun IFRS untuk pertama kali harus mengaplikasikan IFRS secara penuh untuk tahun berjalan dan periode komparatifnya, meskipun terdapat pengecualian transisi (IFRS1.7).

Pada tanggal 6 September 2007, IASB mengeluarkan revisi IAS 1 mengenai penyajian laporan keuangan. Perubahan mendasar dari versi sebelumnya yang menuntut suatu perusahaan harus (1) Menyajikan semua perubahan bukan pemilik (non-owner) dalam ekuitas yang adalah laba komprehensif (comprehensive income), baik dalam satu statement of comprehensive income atau dalam 2 statements (a separate income statement and a statement of comprehensive income). Komponen-komponen dari comprehensive income tidak boleh disajikan dalam the statement of changes in equity, (2) Menyajikan statement of financial position (balance sheet) pada saat awal periode komparatif dalam satu set financial statements sewaktu perusahaan mengaplikasikannya dalam akuntansi, (3) 'balance sheet' akan menjadi 'statement of financial position', (3) 'income statement' akan menjadi 'statement of comprehensive income', dan (4) 'cash flow statement' akan menjadi 'statement of cash flows'. Revisi IAS 1 berlaku efektif untuk periode tahun dimulai atau sesudah 1 Januari 2009. Adopsi lebih awal diijinkan.

\section{METODE PENELITIAN}

Dalam mengkaji konvergensi standar laporan keuangan ke standar pelaporan keuangan internasional, penulis menggunakan metode penelitian isi (content analysis) sebagai acuan kajian tersebut. Penelitian dengan metode ini merupakan analisis terhadap konsep. Analisis konsep merupakan pembuatan eksistensi dan frekuensi konsep yang biasanya dipresentasikan dalam bentuk kata-kata dalam frasa yang terdapat dalam teks (dalam hal ini berupa literatur). Fokus analisis ini ditujukan pada pengamatan terhadap apa dan bagaimana penerapan IFRS dalam pelaporan keuangan yang dianggap penting dan mendukung tujuan penelitian.

Sebagai tolok ukurnya, penulis menggunakan beberapa acuan pustaka seperti buku International Accounting edisi ke 5 (Choi, Frederick D.S., dan Meek, Gary K.) yang menjelaskan konsep-konsep standar akuntansi internasional, kemudian Standar Akuntansi Internasinal (IAS/IFRS) yang merupakan standar akuntansi internasional, yang telah semakin banyak digunakan secara luas di seluruh dunia serta buku Standar Akuntansi Keuangan per 1 Juli 2009, yang merupakan standar akuntansi Indonesia edisi yang paling akhir saat ini, dalam rangka konvergensi menuju kepada Standar Akuntansi Internasional. Atas dasar ketiga buku acuan tersebut, yang merupakan konsep penerapan IFRS ini dijabarkan dampak konvergensi IFRS terhadap bisnis dan perpajakan di Indonesia.

\section{HASIL DAN PEMBAHASAN}

Dengan diimplementasikannya IFRS menggantikan PSAK yang terdahulu, menimbulkan dampak terhadap sistem akuntansi dan pelaporan sebagai berikut. Pertama, penyajian laporan keuangan, yaitu konsep Other Comprehensive Income (OCI) di dalam laba rugi komprehensif; perubahan definisi-definisi seperti kewajiban (liabilitas) dan hak minoritas menjadi bagian non pengendali (non-controlling interest); pos luar biasa tidak lagi diperbolehkan; klasifikasi instrumen keuangan; dan perubahan nama laporan keuangan.

Kedua, pengukuran laporan keuangan, yaitu peningkatan penggunaan nilai wajar (fair value); standar IFRS lebih condong kepada penggunaan nilai wajar, terutama untuk properti investasi, 
beberapa aset tak berwujud, aset keuangan, dan aset biologis. Dengan demikian, diperlukan sumber daya yang kompeten untuk menghitung nilai wajar atau bahkan perlu menyewa jasa konsultan penilai, terutama untuk aset-aset yang tidak memiliki nilai pasar aktif; penggunaan estimasi dan "judgement"; akibat karakteristik IFRS yang lebih berbasis prinsip, akan lebih banyak dibutuhkan "judgement" untuk menentukan bagaimana suatu transaksi keuangan dicatat.

Ketiga, pengungkapan, yaitu persyaratan pengungkapan yang lebih banyak dan lebih rinci; IFRS mensyaratkan pengungkapan berbagai informasi tentang risiko, baik kualitatif maupun kuantitatif; dan pengungkapan dalam laporan keuangan harus sejalan dengan data /informasi yang dipakai untuk pengambilan keputusan yang digunakan oleh manajemen

\section{Dampak Konvergensi IFRS terhadap Bisnis}

Ketua Dewan Pengurus Nasional IAI, Ahmad Hadibroto menyatakan ”Langkah strategis menuju keseragaman 'bahasa' dalam akuntansi dan pelaporan keuangan di sektor privat ini merupakan agenda utama profesi akuntansi secara global. Terciptanya harmonisasi standar akuntansi global juga menjadi salah satu tujuan dan komitmen kelompok G-20 dalam meningkatkan kerjasama perekonomian dunia."

Dengan adanya standar global tersebut, memungkinkan keterbandingan dan pertukaran informasi secara universal. Kovergensi IFRS dapat meningkatkan daya informasi dari laporan keuangan perusahaan-perusahaan yang ada di Indonesia. Adopsi standar internasional juga sangat penting dalam rangka stabilitas perekonomian.

Manfaat dari program konvergensi IFRS diharapkan akan mengurangi hambatan-hambatan investasi, meningkatkan transparansi perusahaan, mengurangi biaya yang terkait dengan penyusunan laporan keuangan, dan mengurangi cost of capital. Sementara itu, tujuan akhirnya laporan keuangan yang disusun berdasarkan Standar Akuntansi Keuangan (SAK) hanya akan memerlukan sedikit rekonsiliasi untuk menghasilkan laporan keuangan berdasarkan IFRS. Banyaknya standar akuntansi yang harus dilaksanakan dalam program konvergensi ini menjadi tantangan yang cukup berat bagi DASK-IAI dan publik untuk sedari awal mengantisipasi implementasi program konvergensi IFRS. Hal tersebut dapat dilihat pada pengalaman pemberlakuan PSAK 50 dan 55 mengenai instrumen keuangan yang telah terbit tahun 2008, yang mendapat tekanan kuat dari ketidaksiapan industri keuangan sehingga harus ditunda penerapannya, maka dapat dibayangkan betapa dahsyatnya memberlakukan puluhan standar dalam waktu singkat.

Selain kesiapan perusahaan-perusahaan, implementasi program ini juga menuntut kesiapan praktisi akuntan manajemen, akuntan publik, akademisi, regulator serta profesi pendukung lainnya seperti aktuaris dan penilai. Akuntan publik diharapkan dapat segera meng-update pengetahuannya sehubungan dengan perubahan SAK, meng-update SPAP dan menyesuaikan pendekatan audit yang berbasis IFRS. Akuntan manajemen/perusahaan dapat mengantisipasi, dengan segera membentuk tim sukses konvergensi IFRS yang bertugas meng-update pengetahuan akuntan manajemen, melakukan gap analysis dan menyusun road map konvergensi IFRS serta berkoordinasi dengan proyek lainnya untuk optimalisasi sumber daya. Akuntan akademisi/ universitas diharapkan dapat membentuk tim sukses konvergensi IFRS untuk meng-update pengetahuan akademis, merevisi kurikulum dan silabus serta melakukan penelitian yang terkait serta memberikan input/komentar terhadap ED dan discussion papers yang diterbitkan oleh DSAK maupun IASB.

Di samping dampak positif, timbul juga dampak negatif dari penerapan IFRS terhadap bisnis, khususnya di Indonesia, yaitu faktor budaya yang terbiasa menggunakan standar akuntansi domestik (yang berlaku di Indonesia) dan sulit untuk mengubah metode ini; jika ingin diterapkan akan membutuhkan waktu yang cukup lama untuk penyesuaiannya. Konvergensi juga menyangkut proses 
penerjemahan bahasa, kadangkala terjemahan yang dibuat dan maksud dari bahasa yang bersangkutan tidak cocok/sesuai sehingga memungkinkan terjadinya persepsi yang berbeda terhdap informasi bisnis tersebut.

Dengan semakin mudahnya para calon investor membaca laporan keuangan di setiap negara yang telah mengadopsi standar IFRS, khususnya negara berkembang, timbul sebuah analisis bahwa terdapat konspirasi politik-ekonomi pihak-pihak tertentu melalui pemberlakuan standar secara global ini untuk mempermudah para penanam modal asing (baca: kapitalis) melakukan pengambil-alihan perusahaan-perusahaan milik negara tanpa kesulitan yang berarti, dengan dalih investasi. Hal ini dapat dirasakan dengan adanya kemudahan proses administrasi, pengesahan undang undang penanaman modal, yang selanjutnya dapat menjadi bom waktu yang siap menghancurkan kekayaan milik negara tersebut. Hal ini dapat dibayangkan melalui film "The new Rules of the World", di mana pemilik modal mengeksploitasi sumber daya alam suatu negara.

\section{Dampak Konvergensi IFRS terhadap Pajak}

Regulator sangat diharapkan untuk melakukan penyesuaian regulasi yang terkait dengan pelaporan keuangan untuk perpajakan. Saat ini terdapat beberapa perbedaan prinsip antara SAK dengan perpajakan sebagai berikut (1) Prinsip estimasi, yakni standar akuntansi keuangan menuntut adanya estimasi dalam berbagai hal seperti impairment loss dan provisi, sedangkan prinsip pajak hanya mengakui realisasi bukan berdasarkan estimasi; (2) Prinsip nilai wajar (fair value), yakni standar akuntansi keuangan memberlakukan secara luas penetapan nilai wajar terhadap aset tetap, properti investasi dan instrumen keuangan, sedangkan prinsip perpajakan memberlakukan prinsip biaya perolehan (cost). (3) Prinsip substance over form, yakni standar akuntansi keuangan memberlakukan prinsip ini terhadap finance lease serta definisi terhadap related parties, sedangkan pajak lebih mendasarkan kepada form over substance, di mana penafsiran sesuatu didasari atas memiliki syarat-syarat yang memperhatikan status legal; (4) Principle based, yakni standar akuntansi keuangan menerapkan principle based yang sangat dominan dalam segala hal, termasuk kaitan related party transaction serta penetapan umur manfaat untuk aset tetap dan aset tak berwujud, sedangkan perpajakan lebih menekankan kepada rule based, di mana semua diatur berdasarkan aturan definisi yang detail; (5) Konsep materialitas, yakni standar akuntansi keuangan menatapkan konsep materiality secara mendalam, khususnya dalam penilaian terhadap suatu laporan keuangan, sedangkan dalam perpajakan tidak mengenal prinsip materialitas.

\section{SIMPULAN}

Penerapan IFRS di Indonesia saat ini merupakan suatu langkah tepat dalam mempersiapkan bangsa Indonesia menuju era perdagangan bebas, meskipun dengan berbagi kendala baik teknis pelaksanaan maupun psikologis berupa ancaman penguasaan asing. Manfaat dari konvergensi diharapkan akan mengurangi hambatan-hambatan investasi, meningkatkan transparansi perusahaan, mengurangi biaya terkait dengan penyusunan laporan keuangan, dan mengurangi biaya modal karena laporan keuangan yang berdasarkan PSAK tidak memerlukan rekonsiliasi signifikan dengan laporan keuangan berdasarkan IFRS. Dengan adanya standar global tersebut, memungkinkan keterbandingan dan pertukaran informasi secara universal. 


\section{DAFTAR PUSTAKA}

Choi, F.D.S., and Meek, G.K. (2005). International accounting, $5^{\text {th }}$ ed., Pearson.

Ikatan Akuntan Indonesia. Standar akuntansi keuangan per 1 Juli 2009, Jakarta: Salemba Empat.

Wolk, Harry I. , Michael G.Tearney, dan James L. Dodd. (2001). Accounting Theory: A Conceptual and Institutional Approuch. Cincinnati, Ohio: Southwestern College Publishing. 